\title{
Penilaian Degradasi Lahan dan Dampak Sedimentasi terhadap Perencanaan Bangungan Air di Daerah Aliran Sungai Wai Ruhu, Kota Ambon
}

\author{
Assessment of Land Degradation and Impact of Sedimentation on Water Structure Planning in the \\ Wai Ruhu Watershed, Ambon City
}

\section{Calvin T. Tutuarima ${ }^{1}$, Silwanus M. Talakua ${ }^{2}{ }^{*}$, Rafael M. Osok $^{2}$}

\author{
${ }^{1}$ Program Studi Pengelolaan Lahan, Program Pascasarjana Universitas Pattimura, Jl. dr. Tamaela-Kampus PGSD, \\ Ambon 97114, Indonesia \\ ${ }^{2}$ Jurusan Budidaya Pertanian, Fakultas Pertanian, Universitas Pattimura, Jl. Ir. M. Putuhena Kampus Poka, Ambon \\ 97233, Indonesia \\ *E-mail Penulis Korespondensi: nustalakua3165@gmail.com
}

\begin{abstract}
Land degradation is the reduction in the ability of land to generate benefits from certain land uses under special treatment from land management. Land degradation usually indicates deterioration in the production capacity of the land either temporarily or permanently. A further consequence of the land degradation process is the emergence of unproductive areas called critical lands. Quantitative and qualitative determination of erosion in a watershed area could be identified through observation of real damage indicators that had occurred in the field. This is based on this study results combined with the method of determining soil degradation in the field, namely the Field Assessment Tools, indicators of soil damage due to erosion obtained in the area of this this study area. These included pedestals, exposed plant roots / tree roots and exposed building foundations as an indication of land degradation due to sheet erosion, channel indicators as channel erosion and trench indicators as trench erosion. The classification of land degradation due to erosion found in the Wai Ruhu watershed showed that the level of land degradation could be classified as light erosion, moderate erosion, heavy erosion and very heavy erosion, with the range of erosion varying from 4.40 tons/ha/year to 675,62 tons/ha/year. Meanwhile, from the results of direct measurements, the overall average sediment concentration was 98,06 $\mathrm{mg} / \mathrm{L}$. During the rainy season, the average sediment concentration produced was 107,43 $\mathrm{mg} / \mathrm{L}$, higher than during the dry season of $88.69 \mathrm{mg} / \mathrm{L}$. The Wai Ruhu watershed had a fairly large discharge. Although during the dry season the river was not dry completely, the discharge was very small. The basic material found along the Wai Ruhu watershed indicated that there had been intensive degradation processes in the upstream area. Excessive deposition along the river would result in reduced capacity of the river channel.
\end{abstract}

Keywords: Ambon, discharge, land degradation, sedimentation, Wai Ruhu Watershed

\begin{abstract}
ABSTRAK
Degradasi lahan adalah berkurangnya kemampuan lahan untuk menghasilkan manfaat dan keuntungan dari penggunaan lahan tertentu di bawah perlakuan khusus dari pengelolaan lahan kerusakan lahan biasanya menandakan kemunduran kapasitas produksi dari lahan baik secara temporer maupun secara permanen. Akibat lanjut dari proses degradasi lahan adalah timbulnya areal-areal yang tidak produktif yang disebut lahan kritis. Penentuan besar erosi secara kuantitatif dan kualitatif pada suatu wilayah DAS dapat diidentifikasi melalui pengamatan terhadap indikator-indikator kerusakan yang nyata terjadi di lapangan. Berdasarkan hasil penelitian yang telah dilakukan ini, yang dipadukan dengan metode penentuan degradasi tanah di lapangan berupa Field Assessment Tools, maka indikator-indikator kerusakan tanah akibat erosi yang didapatkan di daerah penelitian. Itu terdiri dari pedestal, akar tanaman/akar pohon terekspos dan fondasi bangunan terekspos sebagai indikasi degradasi lahan akibat erosi lembar, indikator alur sebagai erosi alur dan indikator parit sebagai erosi parit. Klasifikasi degradasi lahan akibat erosi yang ditemukan di DAS Wai Ruhu menunjukkan bahwa tingkat degradasi lahan tergolong erosi ringan, erosi sedang, erosi berat dan erosi sangat berat, dengan kisaran besar erosi yang bervariasi antara 4,40 ton/ha/tahun sampai 675,62 ton/ha/tahun. Sedangkan dari hasil pengukuran langsung secara keseluruhan konsentrasi sedimen rata-rata adalah sebesar $98,06 \mathrm{mg} / \mathrm{L}$. Untuk saat hujan konsentrasi sedimen rata-rata yang dihasilkan adalah sebesar 107,43 mg/L, lebih tinggi daripada saat kemarau sebesar 88,69 mg/L. DAS Wai Ruhu mempunyai debit yang cukup besar. Meskipun pada saat kemarau aliran sungai tidak kering sama sekali, tetapi debitnya sangat kecil. Material dasar yang terdapat di sepanjang saluran DAS Wai Ruhu menggambarkan bahwa telah terjadi proses-proses degradasi yang intensif di daerah hulu. Pengendapan yang berlebih di sepanjang sungai akan akan mengakibatkan berkurangnya kapasitas saluran sungai.
\end{abstract}

Kata kunci: Ambon, DAS Wai Ruhu, debit air, degradasi lahan, sedimentasi 


\section{PENDAHULUAN}

Pembangunan pertanian di Indonesia dalam beberapa dekade terakhir ini terus ditingkatkan untuk mendukung perekonomian dan kesejahteraan masyarakat, namun di beberapa daerah pembangunan ini telah berdampak terhadap perubahan atau penurunan kualitas (degradasi) sumberdaya lahan. Disamping itu, kerusakan lahan akibat pertambangan dan alih fungsi lahan baik untuk memenuhi kebutuhan lahan bagi kawasan industri maupun pemukiman yang terus meningkat juga merupakan faktor penyebab degradasi lahan di Indonesia (Utomo, 2013; Wahyunto dan Dariah, 2014). Tekanan terhadap ketersedian lahan dan penurunan kualitas lahan akibat degradasi lahan ini terus meningkat dari tahun ke tahun yang ditandai dengan meluasnya lahan kritis dan meningkatnya berbagai fenomena bencana alam, seperti banjir dan tanah longsor (Suprayogo, et al., 2017).

Degradasi lahan (land degradation) adalah berkurangnya kemampuan lahan untuk menghasilkan manfaat dan keuntungan dari penggunaan lahan tertentu di bawah perlakuan khusus dari pengelolaan lahan kerusakan lahan biasanya menandakan kemunduran kapasitas produksi dari lahan baik secara temporer maupun secara permanen (Talakua dan Osok, 2017). Menurut Wahyunto dan Dariah (2014), degradasi lahan disebabkan oleh tiga aspek yaitu fisik, kimia dan biologi. Degradasi fisik terjadi dalam bentuk pemadatan, pergerakan, ketidakseimbangan air, terhalangnya aerasi dan drainase, dan kerusakan struktur tanah. Degradasi kimiawi terjadi akibat dari asidifikasi, pengurasan dan pencucian hara, ketidakseimbangan unsur hara dan keracunan, salinisasi dan pemasaman, alkanisasi serta pencemaran. Sedangkan degradasi biologis antara lain disebabkan karena karbon organik tanah, penurunan keanekaragaman hayati tanah dan vegetasi, serta penurunan karbon biomas. Selain itu, Sitorus et al. (2011) mengatakan bahwa degradasi lahan juga terkait penurunan produktivitas lahan yang sifatnya sementara maupun tetap, yang dicirikan dengan penurunan sifat fisik, kimia dan biologi. Akibat lanjut dari proses degradasi lahan adalah timbulnya areal-ereal yg tidak produktif yang disebut lahan kritis.

Kondisi ini didukung penelitian Sitorus dan Pravitasari (2017) yang menunjukkan bahwa erosi merupakan salah satu penyebab utama degradasi lahan di Indonesia yang diakibatkan oleh tingginya perubahan penggunaan lahan dan aktifitas manusia.

Degradasi lahan di Maluku dapat dikaitkan dengan aktifitas penebangan, ladang berpindah- pindah, konversi lahan dari hutan menjadi perkebunan monokultul dan aktifitas pemanfaatan lahan lainnya yang terjadi di masa lalu. Di Ambon, pertumbuhan penduduk yang cepat telah menyebabkan pertumbuhan kawasan pemukiman dan lahan pertanian yang cepat khususnya pada areal perbukitan dengan topografi agak curam hingga curam. Penelitian Talakua dan Osok (2019) dan Osok, et al. (2018) menunjukkan bahwa penurunan kualitas lahan DAS di Pulau Ambon dan Pulau Seram dapat dikaitkan dengan meningkatnya erosi akibat meluasnya kawasan-kawasan terbangun dan buruknya tutupan lahan pada daerah perbukitan di DAS.

Fenomena erosi, banjir, dan longsor yang terjadi di kota Ambon merupakan fenomena yang sering dilihat pada saat musim hujan. Hal ini mengindikasikan bahwa kualitas DAS-DAS di wilayah Kota Ambon telah menurun (tidak sehat). Di samping itu, luas lahan kritis di wilayah Kota Ambon masih cukup tinggi, yaitu pada tahun 2018 masih mencapai 28.463 ha, yang terdiri dari lahan sangat kritis 5.644 ha, kritis 870 ha, potensial kritis 4.144 ha, agak kritis 14.598 ha, dan tidak kritis 3.207 ha. (BPDASHL WBM, 2019). Kondisi ini turut mendorong terjadinya berbagai masalah lingkungan seperti banjir, erosi dan sedimentasi, tanah longsor yang terjadi setiap tahun pada musim hujan, dan penurunan debit sumber-sumber air bersih dan aliran sungai pada musim kemarau.

Terganggunya fungsi hidrologis DAS di wilayah Kota Ambon ini dipercepat karena DAS- DAS yang berada di pulau Ambon mempunyai topografi dominan berbukit hingga bergunung, dengan kemiringan lereng curam hingga sangat curam $(>30 \%)$.

DAS Wai Ruhu yang terletak pada Desa Galala, Kecamatan Teluk Ambon, Kota Ambon merupakan salah satu DAS yang mengalami erosi, dan banjir dan sedimentasi pada saat hujan. Hal ini terjadi karena DAS Wai Ruhu merupakan kawasan padat penduduk dengan pertumbuhan kawasan pemukiman dan infrastruktur ekonomi yang cepat, tetapi disisi lain kebutuhan lahan yang sesuai peruntukannya sangat terbatas. Oleh sebab itu, penelitian ini dilakukan untuk mengkaji tingkat degradasi lahan yang telah terjadi dan kaitannya dengan penggunaan lahan di DAS Wai Ruhu.

\section{BAHAN DAN METODE}

Penelitian ini menggunakan metode survei berbasis unit lahan sebagai peta kerja lapangan yang didesain berdasarkan hasil tumpang susun (overlay) 4 komponen utama yaitu: kelas topografi, formasi geologi, tanah dan penguunaan penggunaan lahan, Peta penggunaan lahan DAS Wai Ruhu skala 1:10.000 (dari Dr. Ir. Silwanus M. Talakua, MP). Total unit lahan di lokasi penelitian adalah 79 satuan lahan. Pengumpulan data lapangan dilakukan pada sampel area yang mewakili semua unit lahan mengikuti jalur-jalur pengamatan yang telah ditetapkan pada setiap sampel area. Besarnya erosi dihitung pada setiap unit lahan dengan menggunakan metode RUSLE, yaitu $A=R \times K \times$ LS $\times \mathrm{C} \times \mathrm{P}$, dan hasil perhitungan erosi selanjutnya dikoreksi menggunakan model degradasi lahan akibat erosi oleh, $\mathrm{D}=0,2547 \times \mathrm{R} \times \mathrm{K} \times \mathrm{LS} \times \mathrm{C} \times \mathrm{P}$ (Talakua dan Osok, 2017), dimana D adalah besarnya degradasi lahan (ton/ha/tahun), $\mathrm{R}$ adalah nilai erosivitas hujan (ton.m/ha/cm-hujan), $\mathrm{K}$ adalah nilai erodibilitas tanah, LS adalah nilai indeks faktor 
topografi terutama panjang dan kemiringan lereng, $\mathrm{C}$ adalah nilai indeks faktor tanaman atau vegetasi, dan $\mathrm{P}$ adalah nilai indeks faktor tindakan konservasi tanah. Gambar 1 menunjukkan peta lokasi berlangsungnya penelitian.

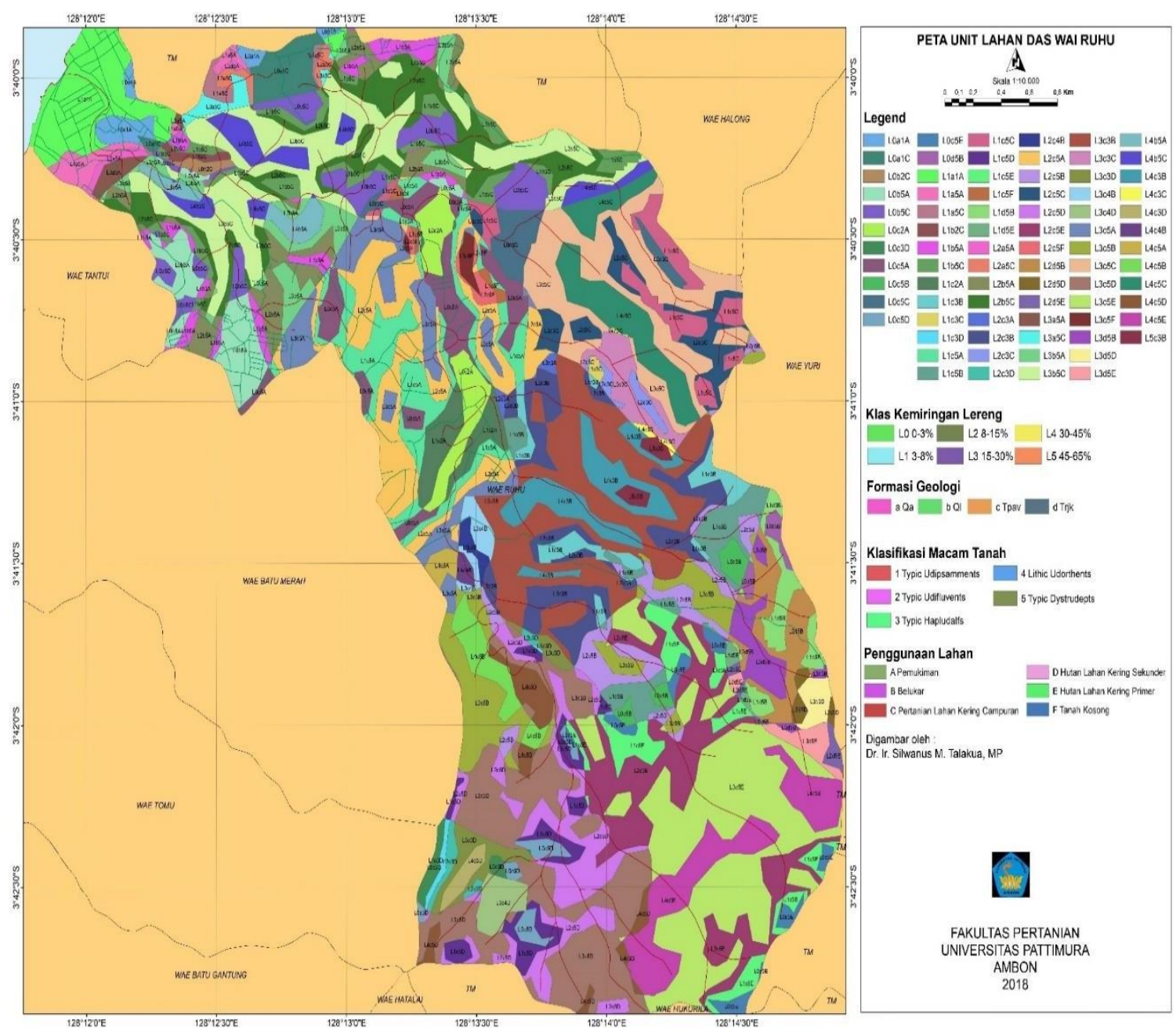

Gambar 1. Peta lokasi penelitian di DAS Wai Ruhu (Negeri Galala dan Hative Kecil, Kecamatan Sirimau, Kota Ambon)

\section{HASIL DAN PEMBAHASAN}

\section{Keadaan Umum Lokasi Penelitian}

\section{Curah hujan}

Hasil data curah hujan selama 9 tahun dengan menggunakan dua data curah hujan dari DAS wai ruhu yaitu pada Pos Curah Hujan Telemetri Halong/Soya dan Pos Curah Hujan daerah sekitar IAIN yang terdapat di DAS Wai Ruhu seperti yang disajikan pada Gambar 2 dan 3 yang menunjukan bahwa curah hujan tahunan pada daerah penelitian bervariasi tiap tahunnya.

Dapat dilihat pada distribusi curah hujan di ke dua stasiun yang berada di DAS Wai Ruhu memiliki rata-rata hujan yang berbeda dan juga puncak terjadi curah hujan biasanya diawali di bulan Juni. Sedangkan bulan yang memiliki curah hujan yang sangat rendah adalah di bulan November.

\section{Topografi}

Dari hasil ini didapatkan bahwa daerah penelitian didominasi oleh kelas topografi L3/miring 603,49 ha atau $37,04 \%$, kemudian kelas topografi L2/agak miring 379,83 ha atau 23,31\%, selanjutnya kelas topografi L1/landai 290,90 ha atau $17,86 \%$, diikuti kelas topografi L0/datar 183,63 ha atau 11,27\% dan kelas topografi L4/agak curam 167,53 ha atau $10,28 \%$ 


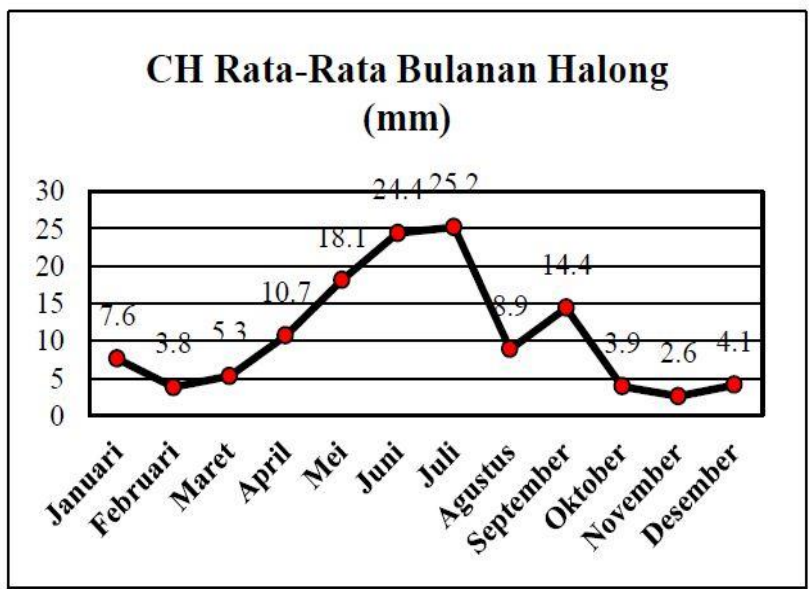

Ganbar 2. Curah hujan rata-rata bulanan di wilayah Halong, Kota Ambon

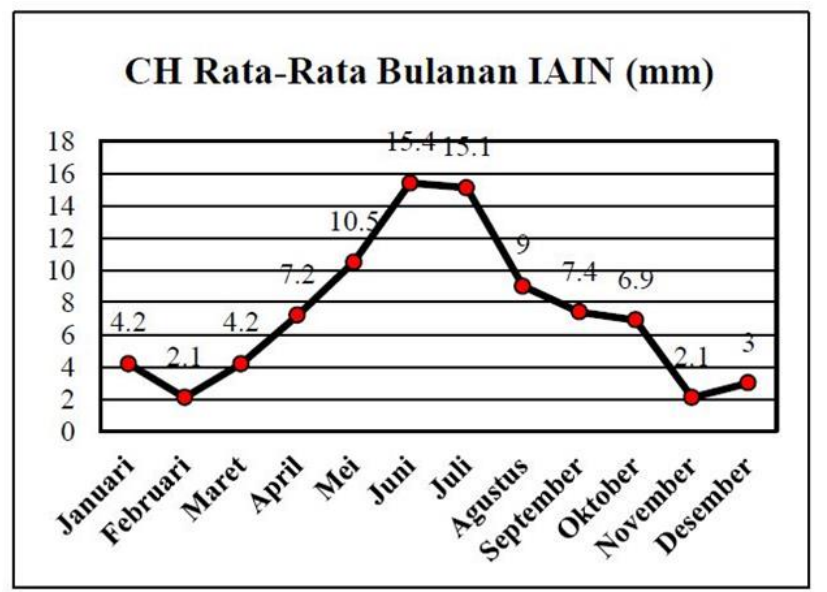

Gambar 3. Curah hujan rata-rata bulanan di wilayah IAIN, Kota Ambon

Kelas topografi yang memiliki luasan sempit, yaitu kelas topografi L5/curam 3,85 ha atau 0,24\% dari total luas daerah penelitian DAS Wai Ruhu. lemiringan lereng (kelas topografi) sangat mempengaruhi laju aliran permukaan suatu lahan. Dimana semakin miring lereng semakin tinggi laju permukaan, sebaliknya semakin datar kemiringan lereng maka semakin rendah laju aliran permukaan. Kondisi ini dapat meningkatkan laju aliran permukaan yang berpotensi untuk menggerus permukaan tanah sehingga degradasi lahan akibat erosi dan sedimentasi dapat meningkat.

\section{Geologi}

Berdasarkan hasil analisis terhadap aspek geologi, menunjukan bahwa daetrah penelitian DAS Wai Ruhu tersusun oleh formasi geologi Tpav (batuan gunung api ambon), Ql (konglomerat), Qa (alluvium), Trjk (formasi kanikeh) dan batu pasir. Berikut Tabel 1 dan gambar dibawah yang mewakili dari masing-masingnya yang tersebar dan cukup luas di daerah penelitian.

Tabel 1. Jenis tanah daerah penelitian DAS Wai Ruhu, Kota ambon

\begin{tabular}{clccc}
\hline No & \multicolumn{1}{c}{ Geologi } & Kode Geologi & Ha & $(\%)$ \\
\hline 1 & Tpav (BatuanGunung Api Ambon) & $\mathrm{c}$ & 1157,26 & 71,03 \\
& & $\mathrm{c}$ & & \\
2 & Q1 (Konglomerat) & $\mathrm{b}$ & 309,66 & 19,01 \\
3 & Qa (Aluvium) & $\mathrm{a}$ & 92,82 & 5,70 \\
4 & Trjk (FormasiKanikeh) & $\mathrm{d}$ & 69,48 & 4,26 \\
\hline \multicolumn{2}{c}{ Total } & & 1629,22 & 100,00 \\
\hline
\end{tabular}

Sumber: Hasil Penelitian, 2018

\section{Klasifikasi Tanah}

Hasil penelitian menunjukan bahwa macam tanah yang terdapat di daerah penelitian adalah Typic Dystrudepts (kambisol distrik), Typic Hapludalfs (brunizem haplik), Typic Udipsamments (regosol eutrik), Typic Udifluvents (aluvial distrik) dan Lithic Udorthents (litosol haplik). Tabel 2 menunjukkan masing-masingnya yang tersebar dan mencakup daerah areal cukup luas di daerah penelitian.

Tabel 2. Jenis Tanah Daerah Penelitian DAS Wai Ruhu.

\begin{tabular}{|c|c|c|c|c|c|}
\hline \multirow[b]{2}{*}{ No. } & \multirow{2}{*}{$\begin{array}{l}\text { Klasifikasi Tanah } \\
\text { (USDA,2006) }\end{array}$} & \multirow{2}{*}{$\begin{array}{c}\text { Padanannya menurut } \\
\text { Klasifikasi Tanah } \\
\text { (PPT,1989) }\end{array}$} & \multirow{2}{*}{$\begin{array}{l}\text { Kode } \\
\text { Tanah }\end{array}$} & \multicolumn{2}{|c|}{ Luas } \\
\hline & & & & ha & $\%$ \\
\hline 1 & Typic Dystrudepts & Kambisol Distrik & 5 & 1280,75 & 78,61 \\
\hline 2 & Typic Hapludalfs & Brunizem Haplik & 3 & 222,10 & 13,63 \\
\hline 3 & Typic Udipsamments & Regosol Eutrik & 1 & 65,17 & 4,00 \\
\hline 4 & Typic Udifluvents & Aluvial Distrik & 2 & 41,95 & 2,58 \\
\hline 5 & Lithic Udorthents & Litosol Haplik & 4 & 19,25 & 1,18 \\
\hline & & & & 1629,22 & 100,00 \\
\hline
\end{tabular}

Sumber: Hasil Penelitian, 2018 


\section{Analisis Degradasi Lahan}

Pada penelitian ini telah dilakukan analisis degradasi lahan dengan metode pengukuran indikator lapangan (field assessment) (Stocking dan Murnaghan, 2000) di DAS Wai Ruhu.

\section{Indikator Degradasi Lahan}

Penentuan besarnya erosi secara kuantitatif dan kualitatif pada suatu wilayah DAS dapat diidentifikasi melalui pengamatan terhadap indikator-indikator kerusakan secara riil yang terjadi di lapangan. Berdasarkan hasil penelitian yang dipadukan dengan metode penentuan degradasi tanah dilapangan yaitu Field Assessment Tools menurut Stocking dan Murnaghan (2000) dalam Talakua (2009), maka indikator-indikator kerusakan tanah akibat erosi yang didapatkan di daerah penelitian meliputi pedestal, akar tanaman/akar pohon terekspos dan fondasi bangunan terekspos sebagai indikasi degradasi lahan akibat erosi lembar (sheet erosion), indikator alur sebagai erosi alur (reel erosion) dan indikator parit sebagai erosi parit (gully erosion).

Berdasarkan hasil penelitian, maka ditemukan bahwa pada unit lahan L0a1A dengan kelas lereng datar (0-3\%), geologi aluvium (Qa), jenis tanah Typic Udipsamments (Regosol Eutrik), dan penggunaan lahan permukiman, ternyata telah mengalami degradasi lahan akibat erosi sebesar 105,73 ton/ha/tahun dan tergolong erosi berat. Hal ini disebabkan karena pada unit lahan tersebut telah terbentuk indikator degradasi lahan akar terekspos sebesar 9,5 mm/tahun, dengan bobot isi tanah $1,143 \mathrm{~g} / \mathrm{cm}^{3}$.

Pada unit lahan L0b5C dengan kelas lereng datar (0-3\%), geologi konglomerat (Q1), jenis tanah Typic Dystrudepts (Kambisol Distrik), dan penggunaan lahan pertanian lahan kering campuran, ternyata telah mengalami degradasi lahan akibat erosi sebesar 233,45 ton/ha/tahun dan tergolong erosi sangat berat. Hal ini disebabkan karena pada unit lahan tersebut telah terbentuk indikator degradasi lahan akar terekspos sebesar 39,5 mm/tahun, dan fondasi bangunan terekspos sebesar 31,43 mm/tahun, dengan bobot isi tanah 1,182 g/ $\mathrm{cm}^{3}$ (Gambar 5).

Pada unit lahan L0c2A dengan kelas lereng datar (0-3\%), geologi batuan gunung api Ambon (Tpav), jenis tanah Typic Udifluvents (Aluvial Distrik), dan penggunaan lahan permukiman, ternyata telah mengalami degradasi lahan akibat erosi sebesar 91,48 ton/ha/tahun dan tergolong erosi berat. Hal ini disebabkan karena pada unit lahan tersebut telah terbentuk indikator degradasi lahan pedestal sebesar 6,29 mm/tahun, dengan bobot isi tanah 1,454 g/cm3 (Gambar $6)$.

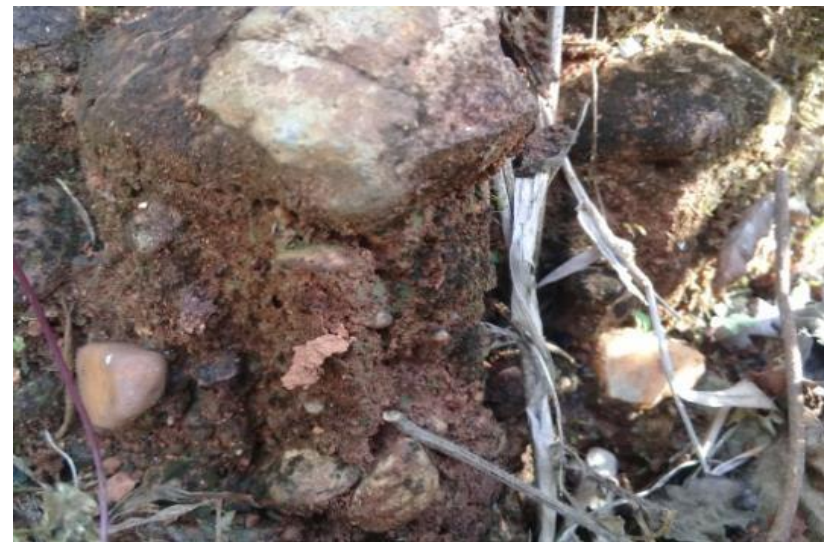

Gambar 6. Indikator pedestal pada unit lahan L0c2A
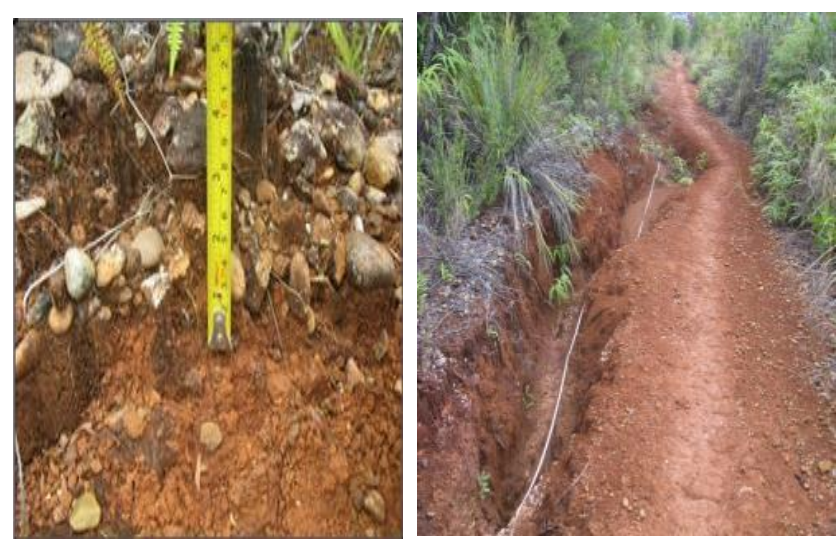

Gambar 7. Indikator pedestal dan alur pada unit lahan L1c5B

Pada unit lahan L1c5B dengan kelas lereng landai (3-8\%), geologi batuan gunung api Ambon (Tpav), jenis tanah Typic Dystrudepts (Kambisol Distrik), dan penggunaan lahan belukar, ternyata telah mengalami degradasi lahan akibat erosi sebesar 112,84 ton/ha/tahun dan tergolong erosi berat. Hal ini disebabkan karena pada unit lahan tersebut telah terbentuk indikator degradasi lahan pedestal sebesar 1,6 mm/tahun, dan parit sebesar 19,11 mm/tahun, dengan bobot isi tanah 0,95 g/cm3 (Gambar 7).

\section{Klasifikasi Degradasi Lahan}

Pada penelitian ini juga telah dilakukan klasifikasi degradasi lahan dengan metode pengukuran indikator lapangan (field assessment) (Stocking dan Murnaghan, 2000; Talakua, 2016) di DAS Wai Ruhu.

Berdasarkan hasil penelitian, sebagaimana disajikan pada Gambar 8, untuk klasifikasi degradasi lahan akibat erosi ditemukan bahwa tingkat degradasi lahan tergolong erosi ringan, erosi sedang, erosi berat dan erosi sangat berat, dengan kisaran besar erosi yang bervariasi antara 4,40 ton/ha/tahun sampai 675,62 ton/ha/tahun. 


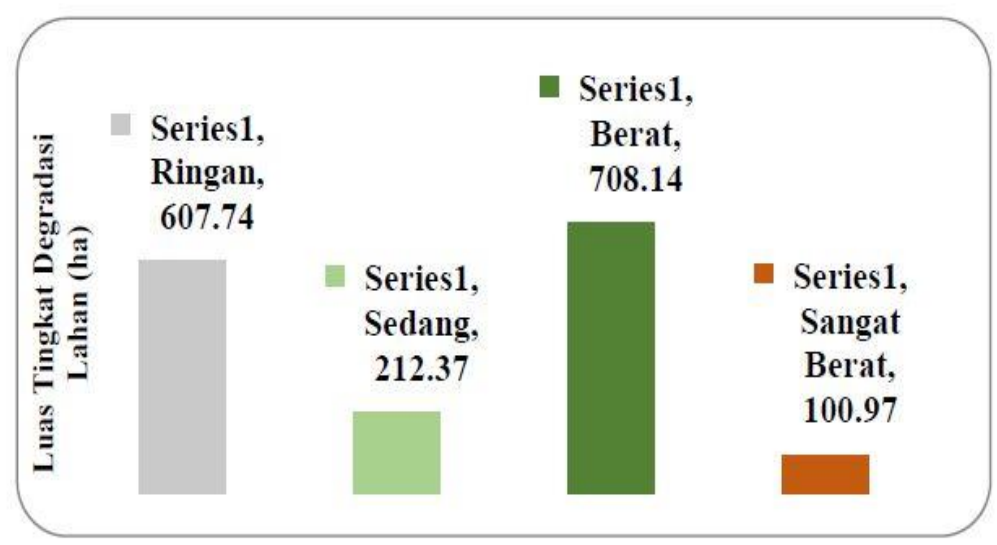

Gambar 8. Luas tingkat degradasi lahan akibat erosi berdasarkan metode pengukuran lapangan (field assassment) di DAS Wai Ruhu

Dari hasil pengamatan besarnya erosi ini yang kemudian dipadukan dengan kriteria tingkat erosi menurut FAO (2004, dalam Talakua, 2009), maka didapatkan bahwa erosi ringan sebesar 4,40 - 19,15 ton/ha/tahun dengan rata-rata erosi sebesar 11,74 ton/ha/tahun seluas 607,74 ha atau 37,30\%. Untuk tingkat degradasi lahan sedang, memiliki besar erosi 22,20 - 49,75 ton/ha/tahun, dengan rata-rata erosi sebesar 34,53 ton/ha/tahun seluas 212,37 ha atau $13,03 \%$. Tingkat degradasi lahan berat, memiliki besar erosi 50,34 -187,73 ton/ha/tahun dengan rata-rata erosi sebesar 114,51 seluas 708,14 ha atau 43,46\%. Untuk tingkat degradasi lahan sangat berat, memiliki besar erosi 202,84 - 675,62 ton/ha/tahun dengan rata-rata erosi sebesar 349,84 seluas 100,97 ha atau 6,20\% dari total luas DAS Wai Ruhu.

\section{Sedimentasi}

\section{Debit aliran sungai berdasarkan musim}

Dari hasil pengkuran secara langsung, menunjukan secara keseluruhan, memiliki debit aliran rata-rata sebesar $0,107 \mathrm{~m}^{3} /$ det dan kecepatan rata-rata sebesar $0,354 \mathrm{~m} /$ detik. Maka dapat dijelaskan bahwa pada saat hujan menghasilkan debit aliran rata-rata sebesar $0,108 \mathrm{~m}^{3} /$ det dengan luas rata-rata $0,299 \mathrm{~m}^{2}$ dan kecepatan rata-rata 0,350 $\mathrm{m} /$ detik, sedangkan pada saat kemarau menghasilkan debit aliran rata-rata $0,106 \mathrm{~m}^{3} / \mathrm{det}$ dengan luas rata-rata $0,284 \mathrm{~m}^{2}$ dan kecepatan rata-rata $0,358 \mathrm{~m} /$ detik. Hal ini disebabkan karena pada musim hujan menyebabkan suplai air dari atmosfir melalui presipitasi sehingga akan meningkatkan debit aliran sungai, sebaliknya pada musim kemarau menyebabkan terjadinya evaporasi dari aliran terbuka sehingga akan menurunkan debit aliran dari sungai.

\section{Konsentrasi sedimen (Cs) DAS Wai Ruhu}

Dari hasil pengukuran langsung yang disajikan pada tabel dan gambar dibawah ini, menunjukkan secara keseluruhan memiliki konsentrasi sedimen rata-rata sebesar 98,06 mg/L. Untuk saat hujan konsentrasi sedimen rata-rata yang dihasilkan sebesar 107,43 mg/L, lebih tinggi dari saat kemarau sebesar 88,69 mg/L. Hal ini disebabkan karena saat saat hujan terjadi penghancuran permukaan tanah oleh energi kinetik hujan (erosivitas hujan) sehingga partikel liat dan debu terlepas dari agregat tanah membentuk suspensi liat dengan aliran permukaan yang akan meningkatkan sedimentasi saat hujan. Indikasinya saat banjir, kondisi sungai lebih keruh dari saat kemarau. Sedangkan untuk saat kemarau, konsentrasi sedimen lebih rendah dari saat hujan, disebabkan karena pada kondisi ini, curah hujan hampir tidak terjadi sehingga tidak ada input sedimentasi dari lereng ke aliran sungai dan sungai cendrung lebih jernih.

\section{Debit sedimen (Qs) DAS Wai Ruhu}

Dari hasil pengukuran langsung seperti yang diasjikan pada tabel dan gambar di bawah ini, menunjukkan secara keseluruhan memiliki debit sedimen (Qs) rata-rata 1,08 ton/hari. Hal ini dapat dijelaskan bahwa tingginya debit sedimen secara keseluruhan karena sudah termasuk saat hujan dan saat kemarau dengan debit (Q) aliran rata-rata sebesar 0,107 m3/detik, dan konsentrasi sedimen (Cs) sebesar 98,06 mg/L.

Untuk saat hujan, debit sedimen (Qs) rata-rata yang dihasilkan sebesar 13,39 ton/hari, lebih tinggi dari saat kemarau sebesar 11,56 ton/hari. Hal ini disebabkan karena saat hujan terjadi penghancuran permukaan tanah oleh energi kinetik hujan (erosivitas hujan) sehingga partikel liat dan debu terlepas dari agregat tanah membentuk suspensi liat dengan tingginya konsentrasi sedimen (Cs) sebesar 107,43 mg/L, yang disertai juga dengan meningkatnya debit aliran sungai $(\mathrm{Q})$ sebesar $0,108 \mathrm{~m}^{3} /$ detik. Indikasinya saat hujan kondisi sungai lebih keruh dan laju aliran meningkat dari saat kemarau. 


\section{Keterkaitan Degradasi Lahan Akibat Erosi (DLAE) dan Sedimentasi Terhadap Penentuan Usia Guna Bangunan Check Dam Wai Ruhu}

Keterkaitan degradasi lahan akibat erosi (DLAE) dan sedimentasi terhadap penentuan usia guna bangunan check dam Wai Ruhu dapat diuraikan sebagai berikut:

1. Pendekatan nilai degradasi lahan akibat erosi di Check Dam Wai Ruhu diperoleh 3806,78 ton/ha/tahun; luas DAS efektif adalah 977,53 ha; SDR = 0,052; angkutan sedimen $(\mathrm{Sy})=197,83 \mathrm{ton} / \mathrm{ha} / \mathrm{tahun} ;$ Sy dalam ton $/$ tahun $=$ 193389,59 ton/tahun; BJ mineral tanah rata-rata $=2,65 \mathrm{ton} / \mathrm{m}^{3}$; laju sedimentasi $=72977,20 \mathrm{~m}^{3} /$ tahun. Maka usia guna check dam Wai Ruhu adalah 0,12 tahun atau1,47 bln atau 44,6 hari. Evalusi sisa usia guna bangunan check dam Wai Ruhu, adalah sebagai berikut:

- Check dam dibangun tahun 2015.

- Pada penelitian yang dilakukan di tahun 2019 sudah terlihat penuh.

- Sudah lebih dari 4 tahun (sejak 2016) bangunan sudah penuh, dan tidak ada pengerukan.

2. Pendekatan sedimentasi di check dam Wai Ruhu tengah-hulu diperoleh konsentrasi sedimen $(\mathrm{Cs})=803,98 \mathrm{mg} / \mathrm{L}$; debit aliran $(\mathrm{Q})=0,91 \mathrm{~m}^{3} /$ detik; debit sedimen $(\mathrm{Qs})=731,62 \mathrm{~g} /$ detik atau 23072,37 ton/tahun; laju sedimentasi $=$ $8706,55 \mathrm{~m}^{3} /$ tahun. Dengan demikian, usia guna check dam Wai Ruhu adalah 1,023 tahun. Evalusi Sisa Usia Guna Bangunan Check Dam Wai Ruhu, yaitu;

- Dibangun tahun 2015.

- Lokasi Check Dam pada bagian tubuh utama sudah ditutupi oleh sedimen.

- Dari awal pembangunan sampai sekarang belum ada pengerukan, sehingga fungsi bangunan tersebut menjadi tidak sempurna (Gambar 9 dan 10).

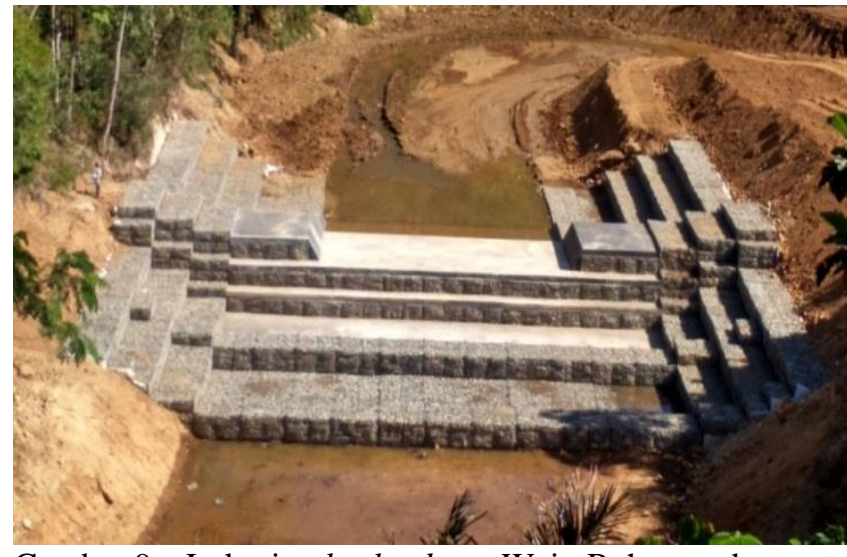

Gambar 9. Lokasi check dam Wai Ruhu pada saat dibangun tahun 2015

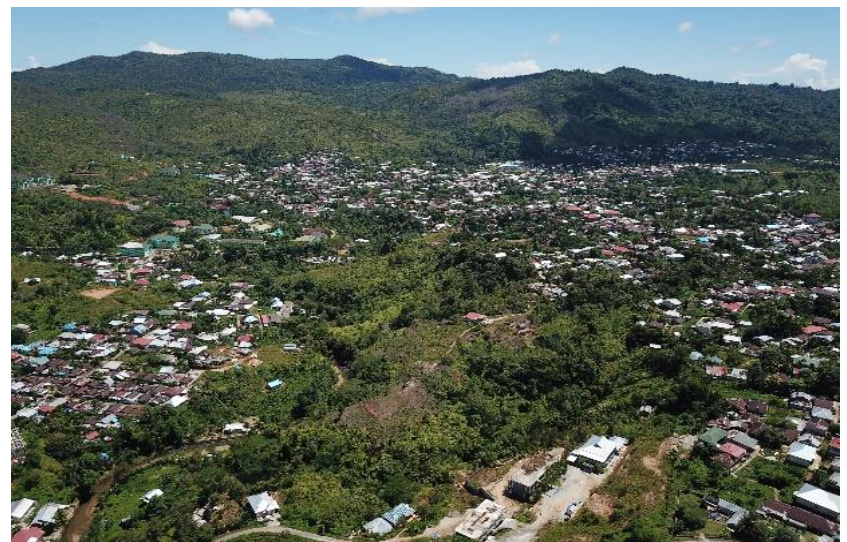

Gambar 10. Kondisi penggunaan lahan di sekitar check dam Wai Ruhu

\section{KESIMPULAN}

\section{Curah hujan}

Dari hasil pemantauan pada DAS Wai Ruhu sebagai lokasi penelitian, dapat dijelaskan bahwa tinggi rendahnya curah hujan akan mempengaruhi fluktuasi volume aliran permukaan DAS dan debit aliran sungai, pada musim kemarau dan hujan. Dimana semakin tinggi curah hujan, semakin besar volume aliran permukaan yang dihasilkan dibandingkan dengan curah hujan yang lebih rendah. Dapat dilihat pada distribusi curah hujan di ke dua stasiun yang berada di DAS Wai Ruhu memiliki rata-rata hujan yang berbeda dan juga jumlah hujan tahunan yang berbeda. PCH Telemtri Halong/Soya sebesar $129 \mathrm{~mm} /$ tahun dan PCH Telemetri IAIN sebesar $87.1 \mathrm{~mm} /$ tahun.

\section{Topografi}

Berdasarkan hasil penelitian lapangan, maka karakteristik topografi DAS Wai Ruhu terdiri atas kelas topografi data (0-3\%), landai (3-8\%), agak miring (8-15\%), miring (15-30\%), agak curam (30-45\%) dan curam (45-65\%).

Dari hasil ini didapatkan bahwa daerah penelitian didominasi oleh kelas topografi L3/miring 603,49 ha atau $37,04 \%$, kemudian kelas topografi L2/agak miring 379,83 ha atau 23,31\%, selanjutnya kelas topografi L1/landai 290,90 ha atau 17,86\%, di ikuti kelas topografi L0/datar 183,63 ha atau 11,27\% dan kelas topografi L4/agak curam 167,53 ha atau $10,28 \%$.

Sedangkan kelas topografi yang memiliki luasan sempit yaitu kelas topografi L5/curam 3,85 ha atau 0,24\% dari total luas daerah penelitian DAS Wai Ruhu. Perlu dijelaskan bahwa kemiringan lereng (kelas topografi) sangat mempengaruhi laju aliran permukaan suatu lahan. Dimana semakin miring lereng semakin tinggi laju permukaan, sebaliknya semakin datar kemiringan lereng maka semakin rendah laju aliran permukaan. Kondisi ini dapat 
meningkatkan laju aliran permukaan yang berpotensi untuk menggerus permukaan tanah sehingga degradasi lahan akibat erosi dan sedimentasi dapat meningkat.

\section{Geologi dan tanah}

Dari aspek geologi, formasi geologi pada DAS Wai Ruhu memiliki jenis batuan yang bervariasi. Jenis batuan yang didominasi oleh batuan gunung api (Tpav) seluas 1157,26 ha (71,03\%), batuan konglomerat (Q1) seluas 309,66 ha $(19,01 \%)$, batuan alluvium (Qa) seluas 92,82 ha (5,70\%) dan batuan formasi kanikeh (Trjk) seluas 69,48 ha (4,26\%). Sedangkan keragaman jenis tanah pada DAS Wai Ruhu mengindikasikan keanekaragaman potensi dan tantangan terkait dengan pengelolaan sumberdaya lahan dan air, sesuai dengan Asdak (2007). Jenis tanah yang didominasi oleh kambisol distrik seluas 1280,75 ha $(78,61 \%)$, brunizem haplik seluas 222,10 ha $(13,63)$, rogosol eutrik seluas 65,17 ha $(4,00 \%)$, alluvial distrik seluas 41,95 ha $(2,58 \%)$ dan litosol haplik seluas 19,25 ha $(1,18 \%)$.

\section{Penggunaan lahan}

Hasil Penelitian dilapangan menunjukan bahwa tipe penggunaan lahan yang ditemui di DAS Wai Ruhu yaitu pertanian lahan kering campuran memiliki penyebaran seluas 399,30 ha atau $24,51 \%$, permukiman memiliki penyebaran seluas 393,36 ha atau $24,14 \%$, belukar memiliki penyebaran seluas 344,09 ha atau $21,12 \%$, hutan lahan kering primer memiliki penyebaran seluas 264,55 ha atau $16,24 \%$, hutan lahan kering sekunder memiliki penyebaran seluas 219,22 ha atau $13,46 \%$ dan tanah kosong memiliki penyebaran seluas 8,70 ha atau 0,53 . selanjutnya penggunaan yang paling terluas sampai yang paling sempit akan disajikan pada tabel dan gambar penggunalan lahan dibawah ini.

Hasil penelitian menunjukkan bahwa luas daerah penelitian DAS Wai Ruhu yaitu 1629,22 ha, sedangkan luas hutan berupa penggunaan lahan hutan kering primer dan hutan lahan kering sekunder yaitu 483,77 ha atau 29,70\%, maka perhitungan indeks lindung DAS yaitu: $483,77 \mathrm{ha} /(0,3 \times 1629,22 \mathrm{ha})=0,990$.

Dari hasil perhitungan, ternyata bahwa IFLdas= 0,990, dan sesuai kriteria maka IFLdas < 1 , berarti kualitas lingkungan DAS relatif terjaga/baik sehingga mampu menjaga fungsi keseimbangan tata guna dan gangguan dari persoalan banjir, erosi, sedimentasi, serta kekurangan air. Penelitian Hidayat et al. (2008), yang telah dilaksanakan sebelumnya menunjukkan dampak negatif perambahan hutan terhadap aliran permukaan dan erosi di DAS.

\section{Degradasi Lahan}

Penyebab degradasi lahan beraneka ragam dan kompleks, dan ada beberapa kencendrungan yang jelas. Satu diantaranya adalah tanah kehilangan kemampuannya untuk dipakai dalam pemanfaatan yang produktif. Dan dapat menurunkan kualitas maupun kerusakan lahan.

Dapat kita lihat secara langsung pada lokasi DAS Wai Ruhu, bedasarkan hasil penelitian lapangan di kombinasi dengan metode Field Assessment Tools menurut Stocking dan Munaghan, 2000 dalam Talakua 2009. Maka hasil peninjauan lapangan pada saat penelitian berlangsung, yaitu fondasi bangunan terekspos, akar terekspos pohon/tanaman, pedestas indikator parit dan indikator alur.

\section{Klasifikasi degradasi lahan}

Klasifikasi degradasi lahan yang dominan pada DAS Wai Ruhu adalah erosi yang disebabkan oleh tigginya faktor-faktor pendorong, yaitu kemiringan lahan dan curah hujan. Jenis degradasi lain adalah kebakaran hutan dan longsor. Klasifikasi lahan akibat erosi yang terdapat di DAS Wai Ruhu bervariasi antara 4.40 ton/hari/tahun sampai dengan 675,62 ton/hari/tahun.

Dari hasil besar erosi ini yang kemudian dipadukan dengan kriteria tingkat erosi menurut FAO (2004) dalam Talakua, 2009), maka didapatkan bahwa erosi ringan sebesar 4,40 - 19,15 ton/ha/tahun dengan rata-rata erosi sebesar 11,74 ton/ha/tahun seluas 607,74 ha atau 37,30\%. Untuk tingkat degradasi lahan sedang, memiliki besar erosi 22,20 49,75 ton/ha/tahun, dengan rata-rata erosi sebesar 34,53 ton/ha/tahun seluas 212,37 ha atau $13,03 \%$. Tingkat degradasi lahan berat, memiliki besar erosi 50,34 - 187,73 ton/ha/tahun dengan rata-rata erosi sebesar 114,51 seluas 708,14 ha atau $43,46 \%$. Untuk tingkat degradasi lahan sangat berat, memiliki besar erosi 202,84-675,62 ton/ha/tahun dengan ratarata erosi sebesar 349,84 seluas 100,97 ha atau 6,20\% dari total luas DAS Wai Ruhu.

\section{Debit Aliran (Q)}

Pada saat setelah hujan debit rata-rata di DAS Wai Ruhu adalah sebesar $108 \mathrm{~m} 3 /$ det dengan kecepatan rata-rata sebesar 0,350 m/det dan pada saat kemarau rata-rata sebesar $106 \mathrm{~m} 3 /$ det dengan kecepatan rata-rata $0,358 \mathrm{~m} / \mathrm{detik}$. Dengan rata-rata keseluruhan sebesar $0,107 \mathrm{~m} 3 /$ det dengan kecepatan rata-rata 0,354 $\mathrm{m} /$ detik.

\section{Konsentrasi Debit Sedimen (Cs) dan Debit Sedimen (Qs)}

Fraksi sedimen muatan dasar pada setiap titik pengambilan sampel terdiri dari kerikil, pasir dan lumpur. Secara umum sedimen yang dominan adalah pasir halus $(0,25-0,125 \mathrm{~mm})$. Konsentrasi sedimen memiliki rata-rata terbesar terletak pada lokasi bagian hilir DAS Wai Ruhu dengan nilai 209,63 mg/L dan nilai konsentrasi sedimen terkecil 
terletak pada lokasi hulu DAS Wai Ruhu nilai 20,63 mg/L. Sedangkan untuk debit sedimen memiliki nilai rata-rata terbesar terletak pada lokasi hilir DAS Wai Ruhu sebesar 2,34 ton/hari dan debit sedimen yang memiliki nilai rata-rata terkecil terletak pada lokasi hulu DAS Wai Ruhu sebesar 0,06 ton/hari.

\section{Keterkaitan Debit Sedimen (Qs) Dengan Degradasi Lahan}

DAS Wai Ruhu mempunyai debit yang sangat besar. Meskipun pada musim kemarau aliran sungai tidak kering sama sekali, tetapi debitnya sangat kecil. Pada musim penghujan debitnya meningkat. Penyebabnya terjadi curah hujan yang berlebih dibandingkan dengan infiltrasi tanah yang ada di daerah penelitian, sehingga Sebagian air hujan berubah menjadi aliran permukaan. Aliran permukaan tersebut terkumpul ke dalam saluran sungai yang mempunyai penyaluran yang tertentu. Apabila aliran air yang ada di dalam saluran melebihi dari kapasitas penyaluran maka terjadilah banjir.

Daerah hulu sampai dengan hilir DAS Wai Ruhu telah berkembang menjadi daerah-daerah pemukian penduduk. Seiring perkembangan dengan perkembangan jumlah penduduknya maka lahan yang tersedia menjadi semakin terbatas. Kerusakan lahan sebagai konsekuensi dan hilangnya lapisan tanah atas karena erosi akan menyebabkan produktivitas tanah semakin menurun, selain itu dengan banyaknya tanah tergerus erosi akan meningkatkan muatan sedimen pada aliran DAS Wai Ruhu dan selanjutnya muatan sedimen ini akan mengendap di aliran sungai, sehingga akan lebih cepat mengalami pendangkalan.

\section{DAFTAR PUSTAKA}

Asdak, C. 2007. Hidrologi dan Pengelolaan Daerah Aliran Sungai. Gadjah Mada University Press. Yogyakarta. ISBN: 978-602-386845-2.

Badan Pusat Statistik (BPS). 2013. Kota Ambon dalam Angka. Badan Pusat Statistik, Kota Ambon.

BPDASHL WBM. 2019. Hasil Review Lahan Kritis Provinsi Maluku. Balai Pengelolaan DAS dan Hutan Lindung Waehapu Batu Merah, Ambon

Hidayat, Y., N. Sinukaban, H. Pawitan, and S.D. Tarigan. 2008. Dampak perambahan hutan terhadap aliran permukaan dan erosi di DAS Nopu Hulu, Sulawesi Tengah. Jurnal Tanah Tropika 13(1): 59-65.

Morgan. 2005. Soil Erosion and Conservation. Blackwell Science Ltd, Oxford. ISBN: 1-4051-1781-8.

Osok, R.M., S.M. Talakua, D. Supriadi, 2018. Penetapan Kelas Kemampuan Lahan Dan Arahan Rehabilitasi Lahan DAS Wai Batu Merah Kota Ambon Provinsi Maluku. Agrologia 7(1): 32-41. DOI: http://dx.doi.org/10.30598/a.v7i1.355

Stocking, M. and N. Murnaghan. 2000. Land Degradation Guideline for Field Assessment. Overseas Development Group University of East Anglia Norwich, UK Co-operating Institutions: United Nations Environment Programme (UNEP), United Nations University (UNU). People, Land Management and Environmental Change Project (PLEC)-Japan.

Sitorus, S., B. Susanto, dan O. Haridjaja. 2011. Kriteria dan klasifikasi tingkat degrdasi lahan. Jurnal Tanah dan Iklim 34:66-83.

Sitorus, S.R.P. and A.E. Pravitasari. 2017. Land degradation and land slide in Indonesia. Sumatra Journal of Disaster, Geography and Geography Education 1(2): 61-71.

Suprayogo, D., Widianto, K. Hairiah, K., dan I. Nita. 2017. Manajemen Daerah Aliran Sungai (DAS): Tinjauan Hidrologi Akibat Perubahan Tutupan Lahan Dalam Pembangunan. Malang: UB Press. ISBN: 978-602-432-403-2.

Talakua. S.M. 2009. Pengaruh Penggunaan Lahan Terhadap Kerusakan Tanah Karena Erosi Di Kecamatan Kairatu Kabupaten Seram Bagian Barat Provinsi Maluku. Disertasi Program Pascasarjana, Universitas Padjadjaran, Bandung.

Talakua, S.M. 2016. Degradasi Lahan Metode Analisis dan Aplikasinya dalam Penggunaan Lahan. Yogyakarta: Penerbit Plantaxia. ISBN: 978-602-6912-13-8.

Talakua, S.M. dan R.M. Osok. 2017. Pengembangan Model Penilaian Degradasi Lahan Berdasarkan Pendekatan Field Assessment. Ambon: Pattimura University Press. ISBN: 978-602-50112-2-1.

Utomo, W.H. 2013. Degradasi Lahan di Indonesia dengan referensi penggunaan Phytomining untuk reklamasi lahan tambang. Prosiding Seminar Nasional Teknologi Pemupukan dan Pemulihan Lahan Terdegradasi dengan Topik Khusus Degradasi Lahan, di Bogor 29-30 Juni 2012, p.15-28. Badan Penelitian dan Pengembangan Pertanian. Jakarta.

Wahyunto, dan A. Dariah. 2014. Degradasi lahan di Indonesia: Kondisi existing, karakteristik, dan penyeragaman definisi mendukung gerakan menuju satu peta. Jurnal Sumberdaya Lahan 8(2): 81-93. DOI: http://dx.doi.org/10.21082/ jsdl.v8n2.2014.\%25p 